Article

\title{
Synergistic Effect in Au-Cu Bimetallic Catalysts for the Valorization of Lignin-Derived Compounds
}

\author{
Marta Stucchi ${ }^{1}{ }^{\circledR}$, Sofia Capelli ${ }^{1}\left(\mathbb{D}\right.$, Simone Cardaci $^{1}$, Stefano Cattaneo $\left.{ }^{1} \mathbb{(}\right)$, Andrea Jouve ${ }^{1}$, \\ Andrea Beck ${ }^{2}$, György Sáfrán ${ }^{3}$, Claudio Evangelisti ${ }^{4}\left(\mathbb{D}\right.$, Alberto Villa ${ }^{1}\left(\mathbb{D}\right.$ and Laura Prati ${ }^{1, *(D)}$ \\ 1 Chemistry Department, University of Milan, Via Golgi 19, 20133 Milan, Italy; marta.stucchi@unimi.it (M.S.); \\ sofia.capelli@unimi.it (S.C.); simone.cardaci@studenti.unimi.it (S.C.); stefano.cattaneo2@unimi.it (S.C.); \\ andrea.jouve@unimi.it (A.J.); alberto.villa@unimi.it (A.V.) \\ 2 Centre for Energy Research, Surface Chemistry and Catalysis Department, P.O. Box 49, \\ H-1525 Budapest, Hungary; beck.andrea@energia.mta.hu \\ 3 Centre for Energy Research, Institute for Technical Physics and Materials Science, P.O. Box 49, \\ H-1525 Budapest, Hungary; safran.gyorgy@energia.mta.hu \\ 4 National Research Centre (CNR)-Istituto di Chimica dei Composti Organometallici, Via G. Moruzzi, 1, \\ 56124 Pisa, Italy; claudio.evangelisti@cnr.it \\ * Correspondence: laura.prati@unimi.it; Tel.: +39-02503-14357
}

Received: 14 February 2020; Accepted: 13 March 2020; Published: 16 March 2020

check for updates

\begin{abstract}
The selective oxidation of veratryl alcohol as lignin-derived compound was studied under mild conditions, using Au-Cu catalysts synthesized from pre-formed nanoparticles with different $\mathrm{Au}: \mathrm{Cu}$ molar ratios. Bimetallic catalysts show higher activity compared to monometallic counterparts, highlighting a clear synergistic effect. By comparing the physico-chemical surface properties of catalysts supported on carbon and $\mathrm{Al}_{2} \mathrm{O}_{3}$, we were able to establish a strong support effect, with alumina-based catalysts being more active than carbon-supported ones. Moreover, TEM and X-ray photoelectron spectroscopy (XPS) analyses showed a different composition of nanoparticles (NPs) and metal exposure, and we established that $\mathrm{Au}$ is the active phase of the reaction. The co-presence of $\mathrm{Au}$ and $\mathrm{Cu}$ species, and their different interaction with the support, enabled obtaining more than $70 \%$ conversion of veratryl alcohol to veratryl aldehyde as a unique product. Moreover, the $\mathrm{Au}_{1} \mathrm{Cu}_{1}$ supported on alumina catalyst was recovered by filtration and reused without significant loss of activity and selectivity up to four times.
\end{abstract}

Keywords: veratryl alcohol; veratraldehyde; $\mathrm{Au}-\mathrm{Cu}$ bimetallic catalysts; support effect; catalytic oxidation; second-generation biomass

\section{Introduction}

The transformation of biomass into fuel and chemicals is becoming increasingly essential as a way to mitigate global warming and diversify energy sources. Biomass is indeed a renewable and carbon-neutral resource. Moreover, it has been estimated that biomass could provide about $25 \%$ of global energy requirements, as well as being a source of valuable chemicals, pharmaceuticals and food additives. Second-generation biomass is mainly composed of cellulose, hemicellulose and lignin. After cellulose, lignin is the second most abundant natural polymer. The aromatic rich structure of lignin has a potential as a feedstock for the production of organic chemicals. However, while designated applications for cellulose already exist, sustainable ways to valorise lignin are yet to be established [1]. Lignin-derived compounds containing significant linkages are commonly used for a better understanding of its catalytic valorisation [2]. Their liquid phase oxidation is a core unit process for producing a variety of fine chemicals [3], with particular interest in the selective oxidation of side 
chain hydroxyl-group of substituted aromatics to aldehydes. Indeed, the selective oxidation of alcohols to the corresponding aldehydes, ketones or acids finds its importance in the pharmaceutical industry as well as in the large-scale chemical industry [4]. Veratryl alcohol (VA) (Figure 1) is a lignin-derived compound, obtained during delignification process in water medium [5].

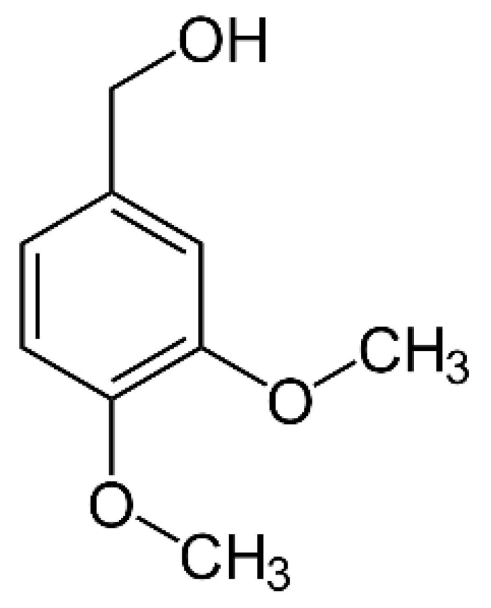

Figure 1. 3,4-dimethoxy benzyl alcohol (veratryl alcohol) molecular structure.

It is used to study the chemical transformation of lignin-derived compounds for the production of biofuels and aromatic chemicals [6]; in particular, VA could be selectively oxidized to veratrylaldehyde (VAld) in the presence of enzymatic catalysts [7], but the high cost and poor stability of the enzymes severely limit their practical application. However, veratraldehyde is desired, being widely used as a flavouring agent and as an important pharmaceutical intermediate for drugs [8].

The oxidation of benzylic system is often reported in the literature, but most of the results are obtained by homogeneous catalysts, which requires the presence of $\mathrm{NaOH}$, phosphate buffer and stoichiometric amount of oxidizing agents [9]. Homogeneous catalysts are disadvantageous, requiring multistep synthesis, often showing fast deactivation and being difficult to recover. For this reason, many researchers investigated the catalytic oxidation on biomass model compounds by heterogeneous catalysis; in fact, the catalytic oxidation of veratryl alcohol by heterogeneous catalysts has already been reported $[10,11]$. Nevertheless, high conversions and selectivity were obtained only under harsh reaction conditions. For example, Rode et al. [10] reported the aqueous phase catalytic oxidation of veratryl alcohol by a nano-structured $\mathrm{Co}_{3} \mathrm{O}_{4}$ catalyst, showing a conversion of $85 \%$ with $96 \%$ selectivity to veratrylaldehyde, where the reaction was carried out at $140^{\circ} \mathrm{C}$ and 40 bar of $\mathrm{O}_{2}$. Moreover, the preparation of the catalyst required continuous stirring for $12 \mathrm{~h}$ at $70{ }^{\circ} \mathrm{C}$ and a calcination step at $300{ }^{\circ} \mathrm{C}$ for $5 \mathrm{~h}$. Riisager et al. [11] reported the oxidative transformation of VA to veratrylaldehyde (VAld) with air, by Ru supported on $\gamma$-alumina or silica: also in this case, the reaction conditions used were harsh, i.e., temperature above $150{ }^{\circ} \mathrm{C}$ and pressure higher than 3 bar. Additionally, the catalysts needed to be calcined at $450{ }^{\circ} \mathrm{C}$ for $6 \mathrm{~h}$.

More recently, Prati et al. [12] reported the oxidation of a lignin model structure including veratryl alcohol at rather mild conditions by Au-Pd on active carbon catalysts. The oxidation of veratryl alcohol was performed at $80^{\circ} \mathrm{C}$ and 2 bar of oxygen, for comparison with the oxidation of benzyl alcohol and 1-methoxy-benzyl alcohol. Despite Au-Pd catalysts converting VA to VAld with $100 \%$ selectivity, the maximum conversion achieved in $6 \mathrm{~h}$ was just $30 \%$ with an initial activity of $151 \mathrm{~h}^{-1}$ (mol converted per mol of metal per hour). In fact, the presence of the methoxy-groups on the aromatic rings led to a strong decrease of activity compared to that obtained in the benzyl alcohol oxidation, due to an irreversible adsorption of the substrate on the metal active site increased by the methoxy-group. At the same time, Chen et al. reported the selective oxidation of veratryl alcohol over Au-Pd supported on ceria-zirconia [13], obtaining a veratryl alcohol conversion of $72 \%$ and selectivity toward VAld of 
$99 \%$. Thus, comparing the results obtained with different supports, it is presumable that the oxidation of veratryl alcohol is support-sensitive, where metal oxide supports may have a strong effect on the catalytic activity.

Considering the metal active species, gold-based catalysts are widely exploited for the oxidation of a variety of hydrocarbons and alcohols [14-16]. Differently from Pt or Pd, Au showed high selectivity and high resistance to $\mathrm{O}_{2}$-poisoning [17], but usually a lower activity. Au-based bimetallic catalysts, however, often showed improved catalytic activity (synergistic effect) and a combination of the properties of the two constituting metals [18].

Copper has been reported to catalyse oxidation of alcohols [19], even presenting quite low conversion, considering the advantage to be an alternative to the more expensive conventional precious metals [20]. It has been shown that the combination of other metals is beneficial. Indeed, although monometallic $\mathrm{Cu}$ did not show a good activity for alcohols oxidation, many works have reported a synergistic effect between gold and copper in oxidation reactions [21,22]. In particular, the oxidation of benzyl alcohol has been reported by M. Rossi et al. [23], using mono- and bimetallic gold-copper on silica catalyst and proving that the bimetallic $\mathrm{Au}-\mathrm{Cu} / \mathrm{SiO}_{2}$ catalyst led to benzaldehyde in over $98 \%$ yield. More recently, C. Evangelisti et al. [24] reported the catalytic activity of some hybrid $\mathrm{Au} / \mathrm{CuO}$ nanoparticles (NPs) supported on carbon for the catalytic liquid-phase selective benzyl alcohol oxidation, demonstrating a strong synergistic effect of $\mathrm{Au} / \mathrm{CuO}$ heterostructures.

Some examples are also reported for the $\mathrm{CO}$ oxidation. Liu et al. [25] reported $\mathrm{Au}-\mathrm{Cu} \mathrm{NPs}$ supported on SBA-15, showing higher activity in CO oxidation than the corresponding monometallic counterparts; the active catalyst was composed of Au NPs enriched on the surface by partially or fully oxidized $\mathrm{CuOx}$, which boosted the $\mathrm{CO} / \mathrm{O}_{2}$ activation. Again, J. Yin et al. [25] reported the $\mathrm{CO}$ oxidation promoted by carbon-supported $\mathrm{Au}-\mathrm{Cu}$ catalysts, where the reduction treatment by hydrogen of the calcined catalyst led to the formation of oxygenated $\mathrm{Cu}$ species at the NPs' surface, able again to activate oxygen with an increase of the catalytic activity.

Here, we investigated the possible synergistic effect between $\mathrm{Au}$ and $\mathrm{Cu}$ at different metal ratio in VA oxidation under mild conditions. The aim of this study is to reduce the presence of precious metals such as gold but also to find a robust catalyst to be applied in VA oxidation. The support effect has been also investigated by using alumina and active carbon as supports.

\section{Results and Discussion}

\subsection{Catalyst Characterization}

\subsubsection{Energy Dispersive X-Ray (EDX) and UV-vis Spectra of the Parent Sols}

The characterization of sols has been performed before their immobilization on the supports. Particular attention was paid to particle composition that normally constitutes a big challenge in bimetallic catalysts. We investigated different Au:Cu molar ratios, namely 4:1, 1:1 and 1:4.

In $\mathrm{Au}_{1} \mathrm{Cu}_{1}$ sol, the $\mathrm{Au}$ and $\mathrm{Cu}$ elemental maps (Figure 2) well demonstrated the co-existence of the two metals in the single particles. The $\mathrm{Au} / \mathrm{Cu}$ atomic ratio varied between 44/66 and 61/39 according to the quantification of the EDS spectra collected on nine particles (the quantified error of the $\mathrm{Au}$ and $\mathrm{Cu}$ atomic concentrations was about $20 \%$ ).

In the $\mathrm{Au}_{4} \mathrm{Cu}_{1}$ (Figure 3) and $\mathrm{Au}_{1} \mathrm{Cu}_{4}$ sols (Figure 4), bimetallic particles were also clearly detected by the elemental maps, although in small size particles high enough intensities could hardly be gained, especially for the lower concentrated component. The $\mathrm{Au}_{1} \mathrm{Cu}_{4}$ contained a high population of smaller low Au content ( $<15$ atomic \%) bimetallic or monometallic $\mathrm{Cu}(\mathrm{Ox})$ particles, in addition to some larger particles of an $\mathrm{Au} / \mathrm{Cu}$ atomic ratio between 52/48 and 78/22. In the case of $\mathrm{Au}_{4} \mathrm{Cu}_{1}$ sol, particles with different atomic composition in the range of $\mathrm{Au} / \mathrm{Cu}=48 / 52$ and 85/15 were detected. 


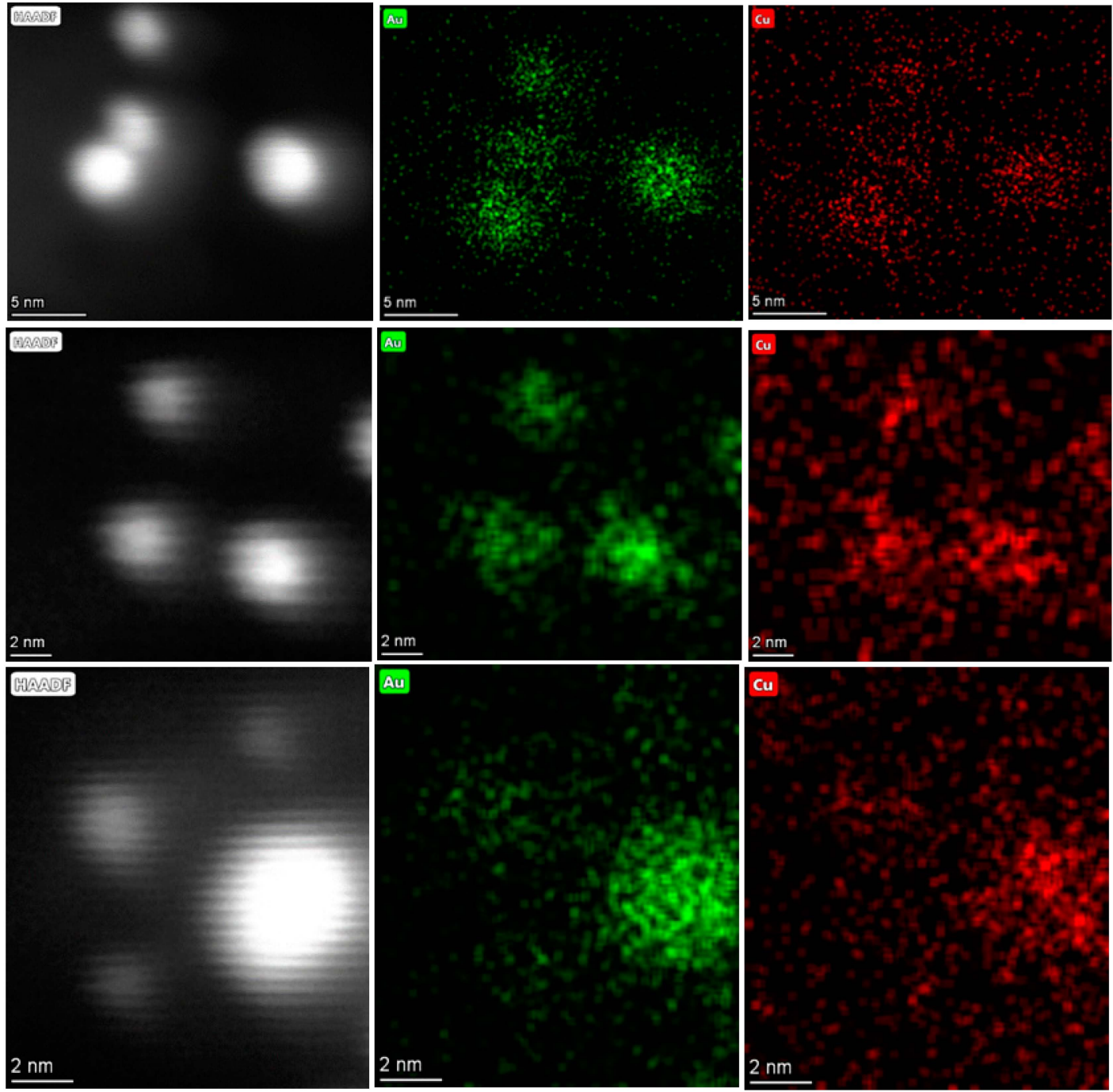

Figure 2. High angular annular dark field (HAADF) images with $\mathrm{Au}$ and $\mathrm{Cu}$ elemental maps (background corrected and fit $\mathrm{Au}-\mathrm{L}$ and $\mathrm{Cu}-\mathrm{K}$ intensities, respectively) recorded during the STEM-EDS measurement of Au1Cu1 sol.

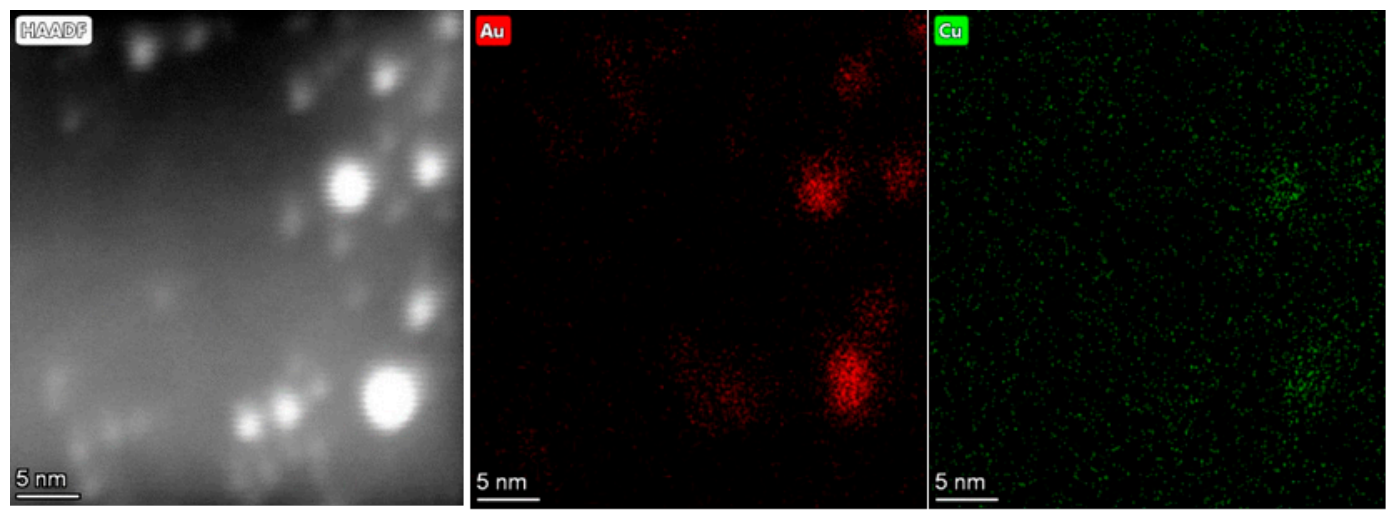

Figure 3. Cont. 

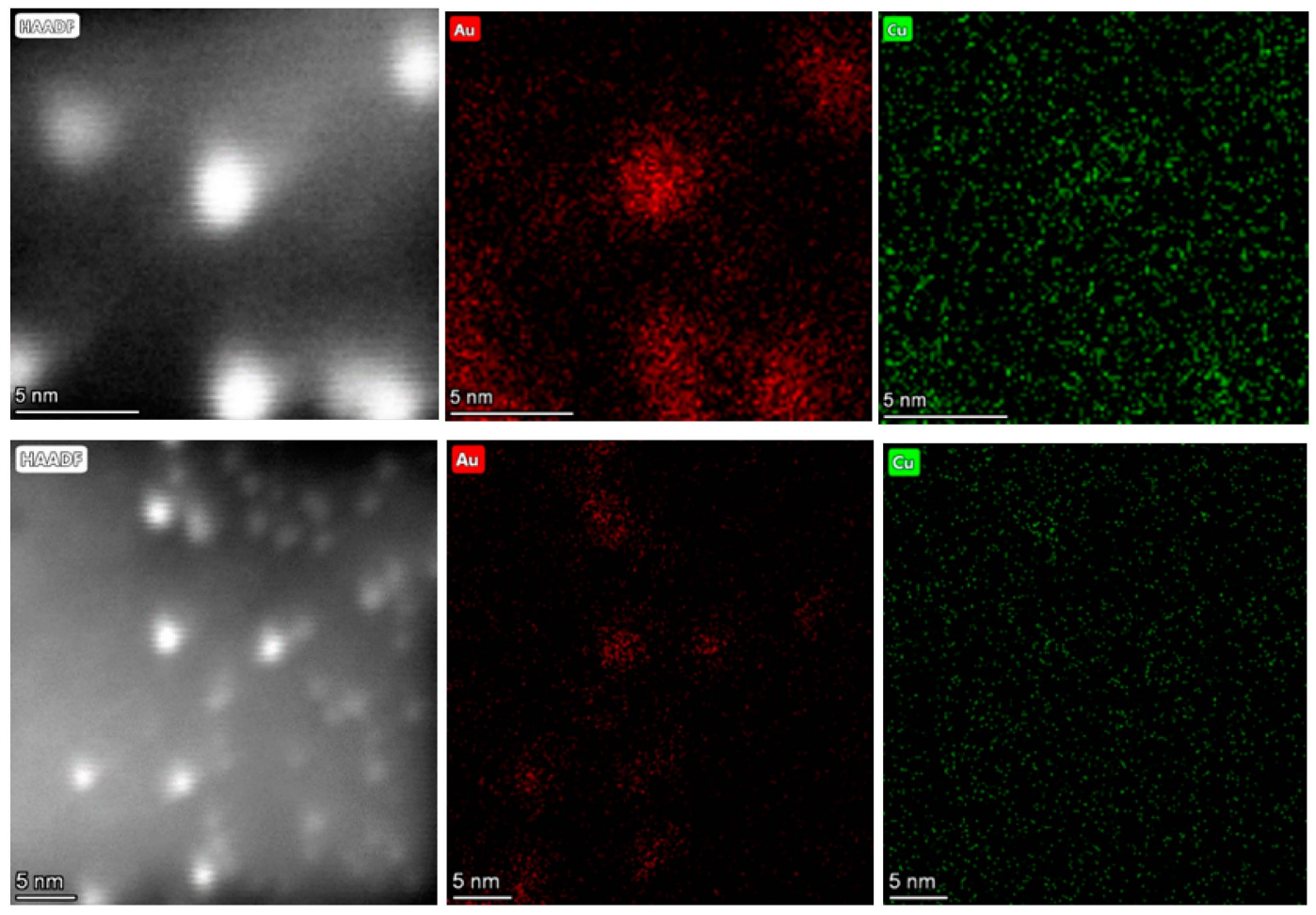

Figure 3. HAADF image with $\mathrm{Au}$ and $\mathrm{Cu}$ elemental maps (background corrected and fit $\mathrm{Au}-\mathrm{L}$ and $\mathrm{Cu}-\mathrm{K}$ intensities, respectively) recorded during the STEM-EDS measurement of $\mathrm{Au}_{4} \mathrm{Cu}_{1}$ sol.
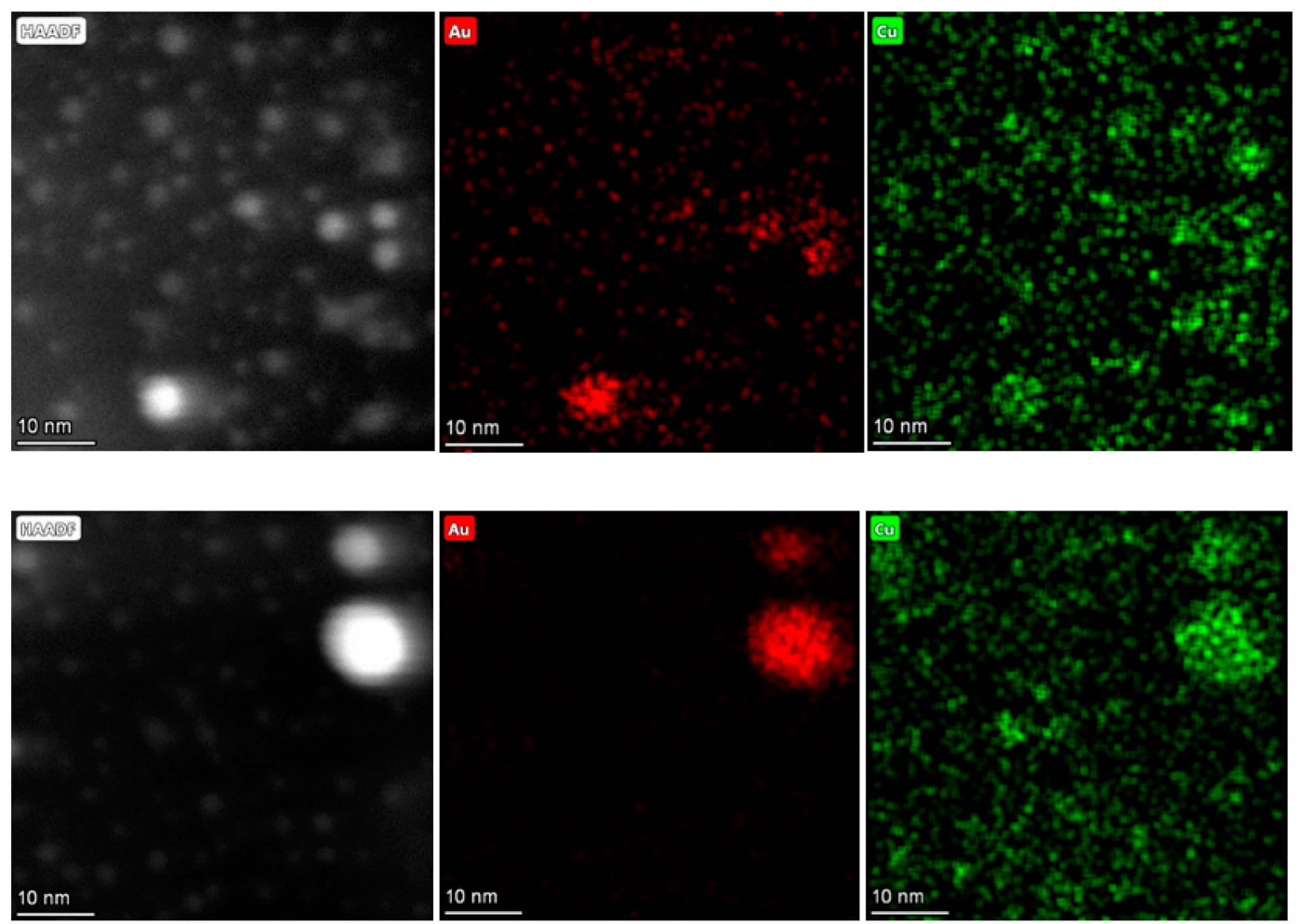

Figure 4. HAADF image with $\mathrm{Au}$ and $\mathrm{Cu}$ elemental maps (background corrected and fit $\mathrm{Au}-\mathrm{L}$ and $\mathrm{Cu}-\mathrm{K}$ intensities, respectively) recorded during the STEM-EDS measurement of $\mathrm{Au}_{1} \mathrm{Cu}_{4}$ sol.

The UV-vis spectra of the parent sols of the different samples are depicted in Figure 5a. The localized surface plasmon resonance (LSPR) bands of the plasmonic Au and Cu containing metal nanoparticles 
located in the 450-700 $\mathrm{nm}$ spectrum range are very weak due to the small particle size of around $2 \mathrm{~nm}$ [26]. For better visibility, the LSPR bands were baseline corrected and enlarged (Figure 5b). The wavelength of the plasmon band of the monometallic Au sol at $516 \mathrm{~nm}$ agrees well with the literature. A characteristic band of Au NP dispersion appears at about $520 \mathrm{~nm}$ [27]. The weak wide band at $632 \mathrm{~nm}$ in the case of monometallic $\mathrm{Cu}$ sol may be attributed to $\mathrm{Cu}$ NPs with $\mathrm{CuOx}$ shell formed due to the facile oxidation of $\mathrm{Cu}$ NPs even at room temperature on air contact. The metallic $\mathrm{Cu}$ NPs are characterized by a plasmon resonance centred at $570-580 \mathrm{~nm}$, that strongly broadens for particles below $4 \mathrm{~nm}[28,29]$. The formation of surface $\mathrm{Cu}_{2} \mathrm{O}$ and the thickening of this oxide shell induces a continuous red shift and a decreasing of intensity by increasing the depth of the oxidized layer [30]. The latter oxidation of $\mathrm{Cu}$ is delayed in alloyed $\mathrm{AuCu}$ particles, as reported in ref. [31]. The plasmon peaks of the $\mathrm{Au}_{4} \mathrm{Cu}_{1}, \mathrm{Au}_{1} \mathrm{Cu}_{1}$ and $\mathrm{Au}_{1} \mathrm{Cu}_{4}$ in bimetallic sols appeared at 533,562 and $578 \mathrm{~nm}$, presenting increasing red shift compared to the Au peak towards that of $\mathrm{Cu}$. The observed plasmon band of $\mathrm{Au}_{4} \mathrm{Cu}_{1}$ is roughly linearly red-shifted from that of a monometallic $\mathrm{Au}$ in proportion to the increase in the mol fraction of $\mathrm{Cu}$, suggesting alloyed particles (disordered alloy formation is assumed). However, for the $\mathrm{Au}_{1} \mathrm{Cu}_{1}$ and $\mathrm{Au}_{1} \mathrm{Cu}_{4}$ sols, these shifts are larger than expected due to alloying. We suppose oxidation of surface copper in these cases, resulting in additional red shift.

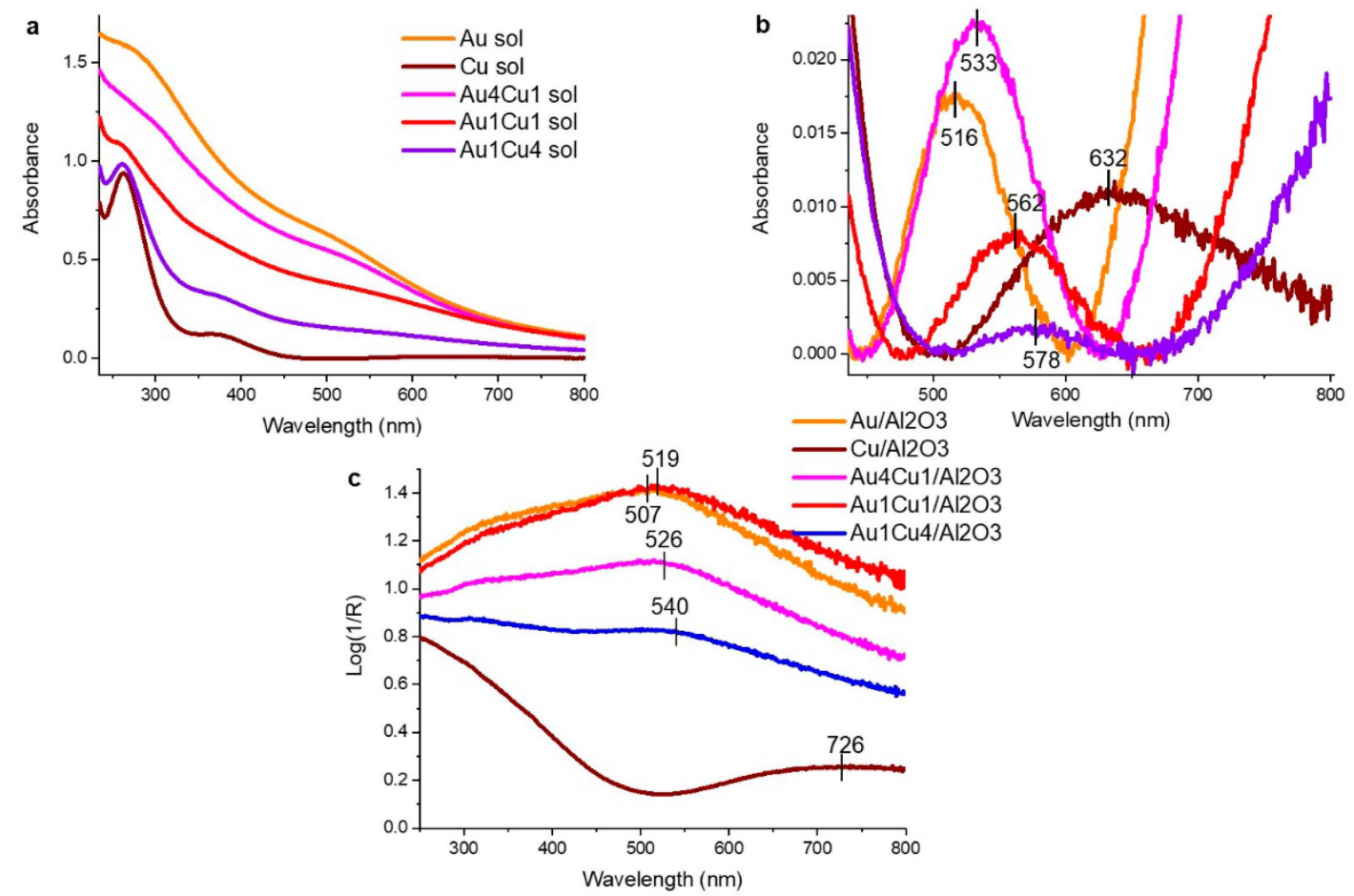

Figure 5. UV-vis spectra of the parent sols (a), the same spectra base line corrected in the localized surface plasmon resonance (LSPR) region (b) and of supported catalysts (c).

In the spectra of sols immobilized on alumina (see Figure 5c), wide weak bands are visible. In the case of the Au-containing samples, the LSPR bands blue shifted relative to those of the corresponding sols, and the difference between them reduced. In $\mathrm{Cu} / \mathrm{Al}_{2} \mathrm{O}_{3}$, the catalyst copper is presumably oxidized. Unfortunately for catalysts supported on carbon, UV-Vis analyses can hardly be carried out due to their low reflection.

\subsubsection{ICP-OES (Inductively Coupled Plasma Optical Emission Spectroscopy) Measurements}

The ICP-OES analyses performed on the supported NPs confirmed the trend revealed by the EDX mapping of the particles: Au-rich catalyst appeared richer than the nominal value, while the $\mathrm{Cu}$-rich catalyst was more rich in copper with respect to the nominal value. ICP-OES was performed using 
a ICP Perkin Elmer optical emission spectrometer Optima 8000 for measuring the actual loading of metal and actual ratio between $\mathrm{Au}$ and $\mathrm{Cu}$. Au-Cu-supported samples were dissolved using a CEM MARS One Microwave Digester, using an acidic solution of $\mathrm{HCl}(37 \%)$ and $\mathrm{H}_{2} \mathrm{SO}_{4}(98 \%)$ at $180{ }^{\circ} \mathrm{C}$ for alumina-supported samples, and using a sulfonitric mixture $\left(\mathrm{HNO}_{3}: \mathrm{H}_{2} \mathrm{SO}_{4} 1: 3\right)$ for carbon supported ones. Au was dissolved by aqua regia $\left(\mathrm{HNO}_{3}: \mathrm{HCl} 1: 3\right)$.

More details about the methodology for catalyst digestion are reported in the Experimental Section. The results are reported in Table 1. The experimental metal loadings are in agreement with the nominal values within the experimental error. The actual $\mathrm{Au} / \mathrm{Cu}$ ratio values are in good agreement with the nominal values considering that the major component is always present in a slightly higher amount with respect to the nominal value: the $\mathrm{Au}_{4} \mathrm{Cu}_{1}$ appears more rich in $\mathrm{Au}$, whereas $\mathrm{Au}_{1} \mathrm{Cu}_{4}$ is more rich in $\mathrm{Cu}$.

Table 1. Nominal and actual metal loadings obtained by inductively coupled plasma (ICP) analyses.

\begin{tabular}{ccccc}
\hline \multirow{2}{*}{ Catalyst } & \multicolumn{2}{c}{ Loading wt. $\%$} & \multicolumn{2}{c}{ Au/Cu mol/mol } \\
\cline { 2 - 5 } & Nominal & Actual & Nominal & Actual \\
\hline $\mathrm{Au} / \mathrm{Al}_{2} \mathrm{O}_{3}$ & 3.0 & 2.7 & - & - \\
$\mathrm{Au}_{4} \mathrm{Cu}_{1} / \mathrm{Al}_{2} \mathrm{O}_{3}$ & 2.6 & 2.2 & 4.00 & 3.61 \\
$\mathrm{Au}_{1} \mathrm{Cu}_{1} / \mathrm{Al}_{2} \mathrm{O}_{3}$ & 2.0 & 1.8 & 1.00 & 0.88 \\
$\mathrm{Au}_{1} \mathrm{Cu}_{4} / \mathrm{Al}_{2} \mathrm{O}_{3}$ & 1.4 & 1.2 & 0.25 & 0.33 \\
$\mathrm{Cu} / \mathrm{Al}_{2} \mathrm{O}_{3}$ & 1.0 & 1.4 & - & - \\
$\mathrm{Au} / \mathrm{C}$ & 3.0 & 2.9 & - & - \\
$\mathrm{Au}_{4} \mathrm{Cu} / \mathrm{C}$ & 2.6 & 2.2 & 4.00 & 3.64 \\
$\mathrm{Au}_{1} \mathrm{Cu} / \mathrm{C}$ & 2.0 & 1.9 & 1.00 & 0.97 \\
$\mathrm{Au}_{1} \mathrm{Cu} / \mathrm{C}$ & 1.4 & 1.5 & 0.25 & 0.26 \\
$\mathrm{Cu} / \mathrm{C}$ & 1.0 & 1.1 & - & - \\
\hline
\end{tabular}

\subsubsection{XPS Analyses}

In order to investigate the nature of surface species and their oxidation state, we used X-ray photoelectron spectroscopy (XPS) which was performed on all the supported bimetallic catalysts (Table 2).

Table 2. X-ray photoelectron spectroscopy (XPS) high-resolution spectra and survey analyses of C-and $\mathrm{Al}_{2} \mathrm{O}_{3}$-supported catalysts.

\begin{tabular}{|c|c|c|c|c|c|c|c|c|c|c|c|}
\hline & & \multicolumn{3}{|c|}{ Survey } & \multicolumn{7}{|c|}{ HR } \\
\hline & & \multicolumn{9}{|c|}{$\operatorname{Au} 4 f_{7 / 2}$} & \multirow[b]{2}{*}{ Sat. } \\
\hline & & $\mathrm{Au}(\% \mathrm{At})$ & $\mathrm{Cu}(\% \mathrm{At})$ & $\mathrm{Au} / \mathrm{Cu}$ & $\mathbf{A u}^{0}$ & $\mathbf{A u}^{\delta+}$ & $\mathrm{Cu}^{0}-\mathrm{Cu}^{+}$ & $\mathrm{CuO}$ & $\mathrm{Cu}(\mathrm{OH})_{2}$ & $\mathrm{Cu}\left(\mathrm{NO}_{3}\right)_{2}$ & \\
\hline \multirow[t]{2}{*}{$\mathrm{Au}_{4} \mathrm{Cu}_{1} / \mathrm{C}$} & B.E. $(e V)$ & & & & 84.3 & 85.5 & - & 933.9 & - & - & \\
\hline & $\%$ At & 0.19 & 0.03 & 6.3 & 77 & 23 & - & 100 & - & - & yes \\
\hline \multirow{2}{*}{$\mathrm{Au}_{1} \mathrm{Cu}_{1} / \mathrm{C}$} & B.E. $(\mathrm{eV})$ & & & & 84.4 & 85.4 & 932.2 & - & - & 935.8 & \\
\hline & $\% A t$ & 0.10 & 0.11 & 0.91 & 74 & 26 & 65 & - & - & 35 & - \\
\hline \multirow[t]{2}{*}{$\mathrm{Au}_{1} \mathrm{Cu}_{4} / \mathrm{C}$} & B.E. $(\mathrm{eV})$ & & & & 83.3 & - & 932.9 & - & 934.5 & - & \\
\hline & $\%$ At & 0.07 & 0.09 & 0.77 & 100 & - & 78 & - & 22 & - & - \\
\hline \multirow[t]{2}{*}{$\mathrm{Au}_{4} \mathrm{Cu}_{1} / \mathrm{Al}_{2} \mathrm{O}_{3}$} & B.E. $(e V)$ & & & & 83.5 & 85.7 & - & 934.0 & - & - & \\
\hline & $\%$ At & 0.97 & 0.53 & 1.83 & 78 & 22 & - & 100 & - & - & yes \\
\hline \multirow{2}{*}{$\mathrm{Au}_{1} \mathrm{Cu}_{1} / \mathrm{Al}_{2} \mathrm{O}_{3}$} & B.E. $(\mathrm{eV})$ & & & & 83.5 & 86.1 & 932.9 & - & - & 935.6 & \\
\hline & $\%$ At & 0.64 & 0.84 & 0.76 & 83 & 17 & 61 & - & - & 39 & - \\
\hline \multirow[t]{2}{*}{$\mathrm{Au}_{1} \mathrm{Cu}_{4} / \mathrm{Al}_{2} \mathrm{O}_{3}$} & B.E. $(\mathrm{eV})$ & & & & 83.7 & - & 932.7 & - & 934.6 & - & \\
\hline & $\%$ At & 0.16 & 1.36 & 0.12 & 100 & - & 70 & - & 30 & - & - \\
\hline
\end{tabular}

The $\mathrm{Au} / \mathrm{Cu}$ ratio evaluated from survey spectra shows that in the carbon-supported catalysts, only in the case of $\mathrm{Au}_{1} \mathrm{Cu}_{1}$, the surface composition is around 1, whereas in both Au-rich and Cu-rich catalysts we observed a surface enrichment of $\mathrm{Au}$; in all three alumina-supported samples, $\mathrm{Cu}$ was enriched on the surface compared to the bulk composition.

From high-resolution spectra (HR) of $\mathrm{Au} 4 \mathrm{f}_{7 / 2}$, two main species were clearly detected: $\mathrm{Au}^{0}(83.5-84.4 \mathrm{eV})$ and $\mathrm{Au}^{\delta+}(85.4-86.1 \mathrm{eV})$. $\mathrm{Au}^{0}$ was always the main component and for C-supported samples its amount was $74 \%$ and $77 \%$ for $\mathrm{Au}_{1} \mathrm{Cu}_{1}$ and $\mathrm{Au}_{4} \mathrm{Cu}_{1}$, respectively. Instead, for $\mathrm{Al}_{2} \mathrm{O}_{3}$-supported 
catalysts the $\mathrm{Au}^{0}$ amount is higher: $83 \%$ and $78 \%$ for $\mathrm{Au}_{1} \mathrm{Cu}_{1}$ and $\mathrm{Au}_{4} \mathrm{Cu}_{1}$ samples, respectively. Of particular interest is the presence of $100 \%$ of $\mathrm{Au}^{0}$ in $\mathrm{Au}_{1} \mathrm{Cu}_{4}$ samples both on carbon and $\mathrm{Al}_{2} \mathrm{O}_{3}$ support.

Regarding the $\mathrm{HR}$ of $\mathrm{Cu} 2 \mathrm{p}_{3 / 2}$, four main components were detected, even if it was impossible to separate the contribution of $\mathrm{Cu}^{0}$ and $\mathrm{Cu}^{+}$. $\mathrm{Cu}^{0}-\mathrm{Cu}^{+}$was detected at $932.2-932.9 \mathrm{eV}, \mathrm{CuO}$ at 933.9-934.0 eV and $\mathrm{Cu}(\mathrm{OH})_{2}$ at $934.5-934.6 \mathrm{eV}$. $\mathrm{Au}_{4} \mathrm{Cu}_{1}$ samples show the presence of only $\mathrm{CuO}$ with the satellite peak of $\mathrm{Cu}^{\mathrm{II}}$, which is, however, not possible to quantitatively evaluate due to the low signal intensity. In $\mathrm{Au}_{1} \mathrm{Cu}_{1}$ samples, $\mathrm{Cu}^{0}-\mathrm{Cu}^{+}$was detected in similar amounts: $65 \%$ and $70 \%$ on carbon and $\mathrm{Al}_{2} \mathrm{O}_{3}$, respectively. Moreover, these two samples also show the presence of a peak which could be tentatively assigned to $\mathrm{Cu}\left(\mathrm{NO}_{3}\right)_{2}$, which was the metal precursor used during the synthesis of the sol. However, although the deconvolution seems to point out the presence of a peak, the assignment to $\mathrm{Cu}\left(\mathrm{NO}_{3}\right)_{2}$ appears uncertain as the catalyst was repeatedly washed, thus assuring the removal of residual copper nitrate. Moreover, this peak is visible only in the case of Au1Cu1 catalyst and no evidence of a satellite peak of $\mathrm{Cu}$ (II) is present.

Finally, $\mathrm{Au}_{1} \mathrm{Cu}_{4}$ samples revealed the presence of $\mathrm{Cu}^{0}-\mathrm{Cu}^{+}$and $\mathrm{Cu}(\mathrm{OH})_{2}$, being the first one the main species. The presence of $\mathrm{Cu}^{\mathrm{II}}$ in the catalysts prepared with a low amount of $\mathrm{Cu}$ is possibly the result from the redox reaction between $\mathrm{Cu}^{0}$ and $\mathrm{Au}^{\delta+}$ [32]. Therefore, in these samples, most of $\mathrm{Cu}$ probably underwent this reaction. On the other hand, when $\mathrm{Cu}$ is present in a large amount with respect to $\mathrm{Au}$, the internal redox can be stopped and it can remain as $\mathrm{Cu}^{0}$ or passivated by air.

\subsubsection{High Angular Annular Dark Field Scanning Transmission Electron Microscopy (HAADF-STEM)}

The particle size distribution and dispersion of the metallic particles of $\mathrm{AuCu}$ bimetallic catalysts was investigated by HAADF-STEM. Representative micrographs of the bimetallic AuCu catalysts supported on alumina and carbon are reported in Figures 6 and 7, respectively, together with their particle size distribution. 

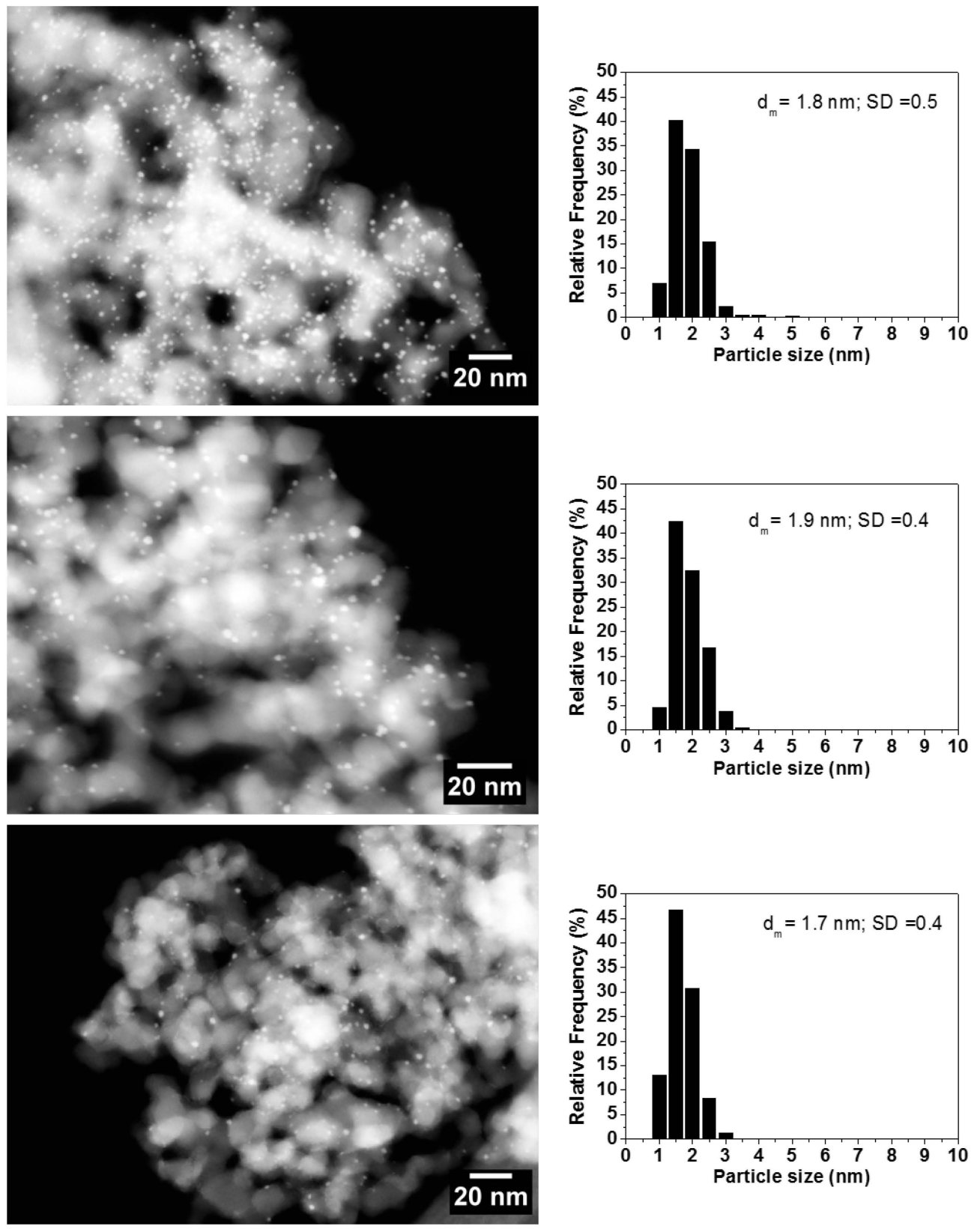

Figure 6. Representative HAADF-scanning transmission electron microscopy (STEM) micrograph and particle size distribution of $\mathrm{Au}_{4} \mathrm{Cu}_{1} / \mathrm{Al}_{2} \mathrm{O}_{3}$ (top), $\mathrm{Au}_{1} \mathrm{Cu}_{1} / \mathrm{Al}_{2} \mathrm{O}_{3}$ (middle), $\mathrm{Au}_{1} \mathrm{Cu}_{4} / \mathrm{Al}_{2} \mathrm{O}_{3}$ (bottom). 

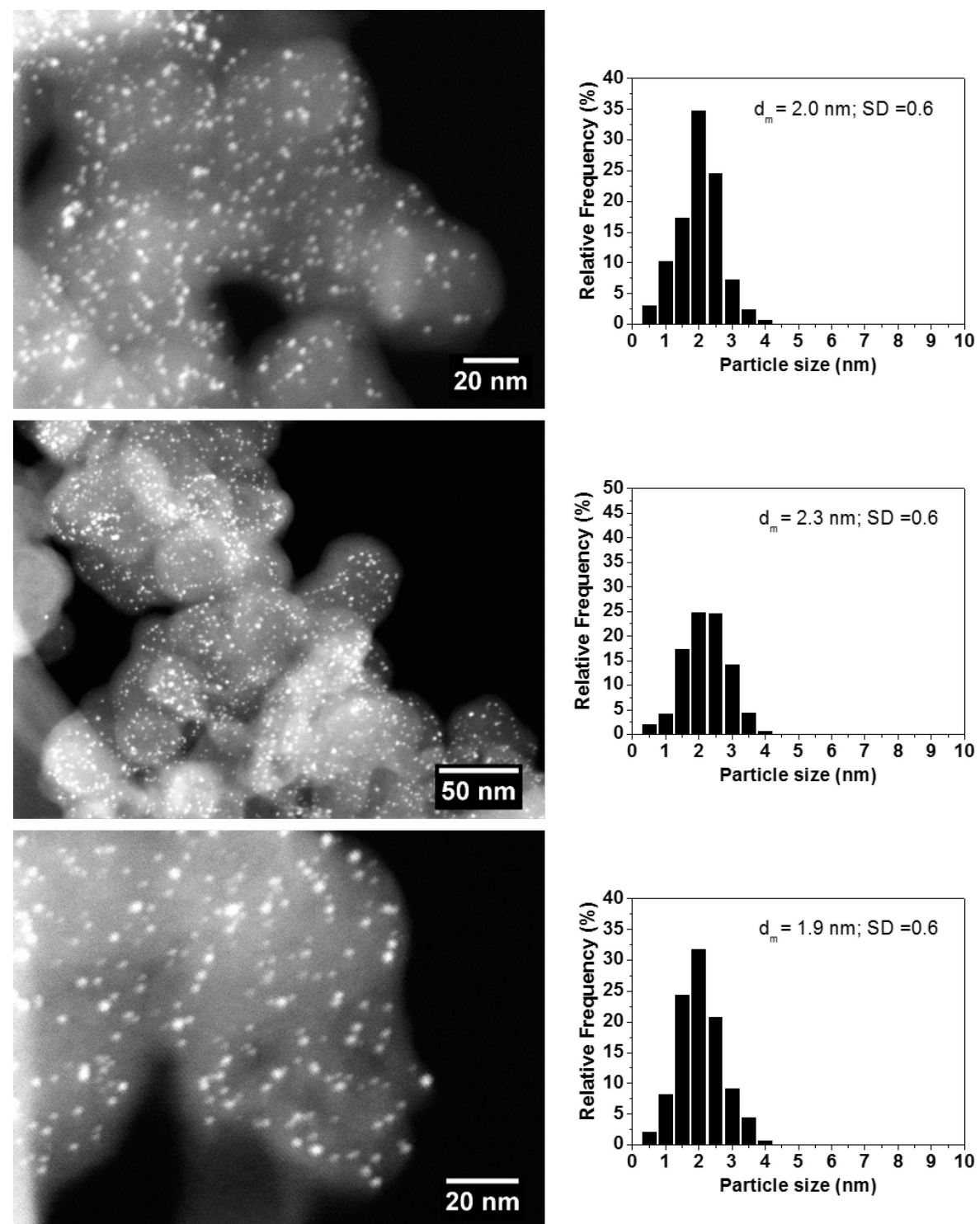

Figure 7. Representative HAADF-STEM micrograph and particle size distribution of $\mathrm{Au}_{4} \mathrm{Cu}_{1} / \mathrm{C}$ (top), $\mathrm{Au}_{1} \mathrm{Cu}_{1} / \mathrm{C}$ (middle), $\mathrm{Au}_{1} \mathrm{Cu}_{4} / \mathrm{C}$ (bottom).

In all the bimetallic samples, a high metal dispersion was observed. Alumina-supported $\mathrm{AuCu}$ bimetallic samples (Figure 6) showed very similar particle size $\left(\mathrm{d}_{\mathrm{m}}=1.7-1.9 \mathrm{~nm}\right)$ and distributions, regardless the $\mathrm{AuCu}$ molar ratio.

In the carbon-supported $\mathrm{AuCu}$ bimetallic catalysts (Figure 7), the support appeared densely populated by nanometric metal particles. The $\mathrm{Au} / \mathrm{Cu}$ molar ratio did not significantly affect the particle sizes which showed a slight increase with respect to the alumina-supported samples $\left(d_{m} 1.9 \mathrm{~nm}-2.3 \mathrm{~nm}\right)$.

\subsection{Catalytic Behaviour}

Testing all the carbon-supported catalysts in VA oxidation at $80{ }^{\circ} \mathrm{C}$ and 2 bar of oxygen pressure (Figure 8), we observed a negligible activity, reaching, in all cases, conversions of $<10 \%$ after $6 \mathrm{~h}$. Notably, the monometallic $\mathrm{Cu} / \mathrm{C}$ was completely inactive. This was not unexpected as in the literature it has been reported that the $\mathrm{Cu}$ species are unable to activate $\mathrm{O}_{2}$ and they do not act as active sites [25]. 


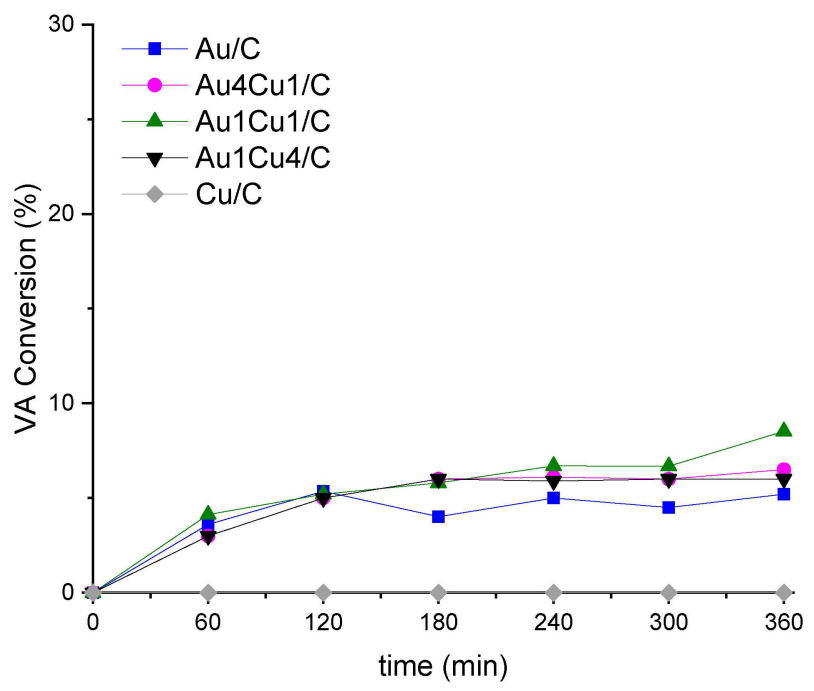

Figure 8. Veratryl alcohol (VA) conversion as a function of reaction time by $\mathrm{Au}, \mathrm{Cu}$ and $\mathrm{Au}-\mathrm{Cu}$ supported on carbon. Reaction conditions: $80^{\circ} \mathrm{C}, 2$ bar of $\mathrm{O}_{2}$, VA $0.15 \mathrm{M}$ in p-xylene, VA: metal molar ration 1000:1.

A strong support effect could be hypothesized by comparing carbon-supported catalysts with alumina-supported ones (Figure 9). $\mathrm{Au}_{4} \mathrm{Cu}_{1} / \mathrm{Al}_{2} \mathrm{O}_{3}$ reached 70\% conversion of VA with respect to less than $10 \%$ obtained by the same composition supported on carbon. As in the case of $\mathrm{Cu} / \mathrm{C}$, monometallic $\mathrm{Cu}$ supported on $\mathrm{Al}_{2} \mathrm{O}_{3}$ did not show any activity.

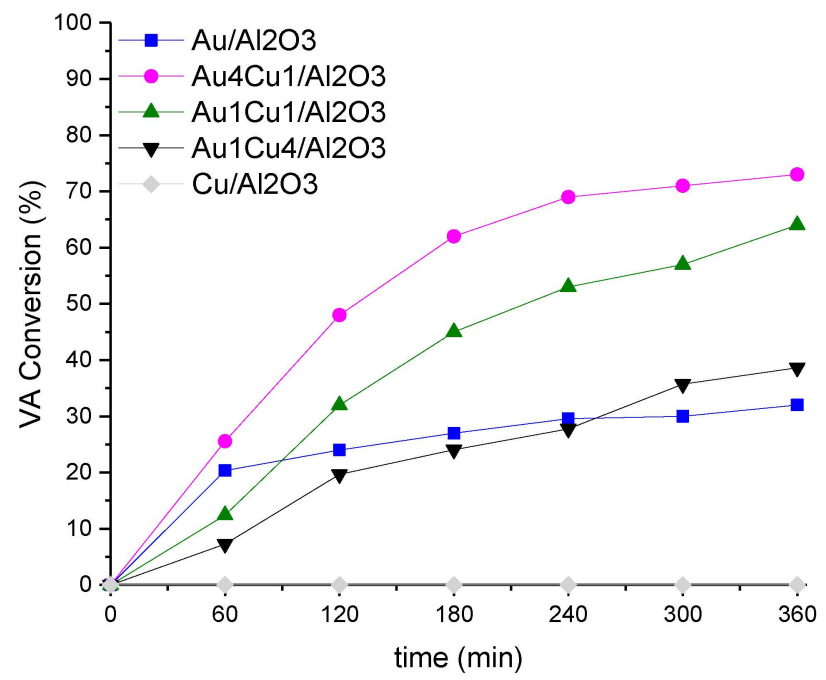

Figure 9. VA conversion as a function of reaction time by $\mathrm{Au}-$ and $\mathrm{Au}-\mathrm{Cu}$ supported on alumina. Reaction conditions: $80^{\circ} \mathrm{C}, 2$ bar of $\mathrm{O}_{2}$, VA $0.15 \mathrm{M}$ in p-xylene, VA: metal molar ration 1000:1.

In terms of initial activity (defined as mol converted per mol of metal per hour), $\mathrm{Au} / \mathrm{Al}_{2} \mathrm{O}_{3}$ showed an initial activity of $200 \mathrm{~h}^{-1}$ (Figure 10) and converted $30 \%$ of VA in $6 \mathrm{~h}$ (Figure 9). The initial activity for $\mathrm{Au}_{4} \mathrm{Cu}_{1} / \mathrm{Al}_{2} \mathrm{O}_{3}, \mathrm{Au}_{1} \mathrm{Cu}_{1} / \mathrm{Al}_{2} \mathrm{O}_{3}$ and $\mathrm{Au}_{1} \mathrm{Cu}_{4} / \mathrm{Al}_{2} \mathrm{O}_{3}$ are, respectively, 250, 120 and $60 \mathrm{~h}^{-1}$. On the basis of these data, we could suppose the presence of a slight synergistic effect considering the decreased amount of Au. However, looking at the reaction profile reported in Figure 9, it clearly appears that bimetallic catalysts showed an improved resistance to deactivation with respect to $\mathrm{Au} / \mathrm{Al}_{2} \mathrm{O}_{3}$, which tends to deactivate after $1 \mathrm{~h}$ of reaction. On this aspect, the catalyst which shows the higher resistance appears to be the $\mathrm{Au}_{1} \mathrm{Cu}_{1} / \mathrm{Al}_{2} \mathrm{O}_{3}$ (green line in Figure 9). 


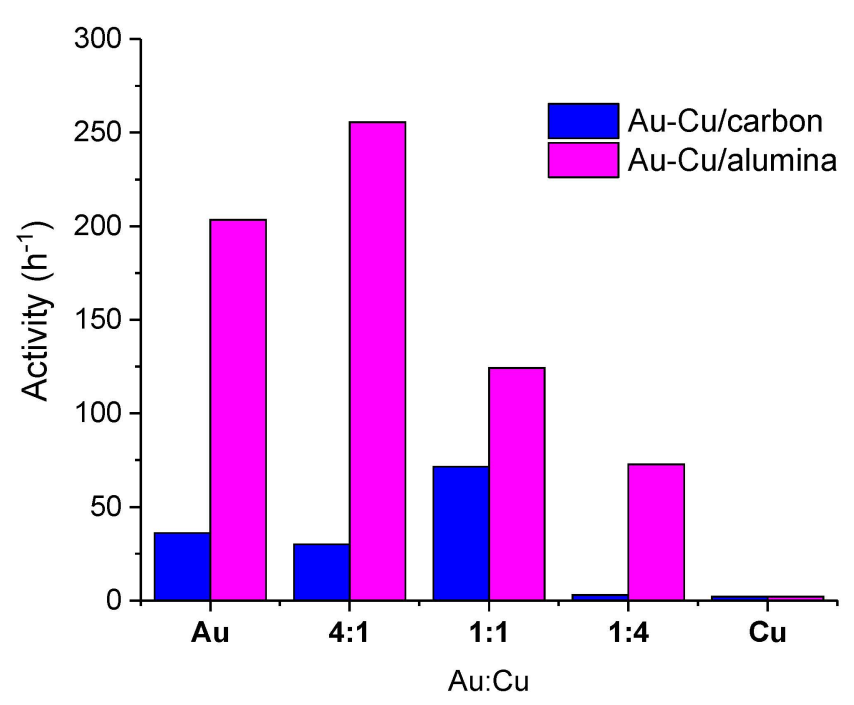

Figure 10. Initial activity $\left(\mathrm{h}^{-1}\right)$ (mol converted per mol of metal per hour) calculated at $1 \mathrm{~h}$ of reaction as a function of the $\mathrm{Au} / \mathrm{Cu}$ molar ratio. Comparison between alumina- and carbon- supported $\mathrm{Au}$ and Au-Cu catalysts.

Comparing the initial activity of $\mathrm{Al}_{2} \mathrm{O}_{3}$ - and C-supported catalysts (Figure 10) we could note a volcano trend only in the case of the $\mathrm{Al}_{2} \mathrm{O}_{3}$-supported catalysts. Therefore, copper positively influences the catalyst activity when it is added in low amount.

\subsubsection{Correlation of Catalytic Results and Characterization}

Considering that supported NPs have a similar particle sizes, we can exclude the effect of this parameter on the catalytic behavior. Contrarily, considering the catalytic results and XPS analyses, we found that the activity is influenced by the support and the catalyst surface composition. The $\mathrm{C}$-supported catalysts show lower $\mathrm{Au}$ exposure and lower conversion than the $\mathrm{Al}_{2} \mathrm{O}_{3}$-supported ones (Figure 11, Table 2). The higher the Au surface exposure, the higher the conversion. Considering the samples $\mathrm{Au}_{4} \mathrm{Cu}_{1} / \mathrm{C}$ and $\mathrm{Au}_{1} \mathrm{Cu}_{4} / \mathrm{Al}_{2} \mathrm{O}_{3}$, with the same $\mathrm{Au}$ exposure, we expected the same conversion if the support does not influence the reaction. However, the conversions in these two cases are different $\left(\mathrm{Au}_{1} \mathrm{Cu}_{4} / \mathrm{C} 3 \%_{3}\right.$ and $\mathrm{Au}_{1} \mathrm{Cu}_{4} / \mathrm{Al}_{2} \mathrm{O}_{3} 7 \%$-Table 3). Therefore, the choice of the support plays a key role in VA oxidation.

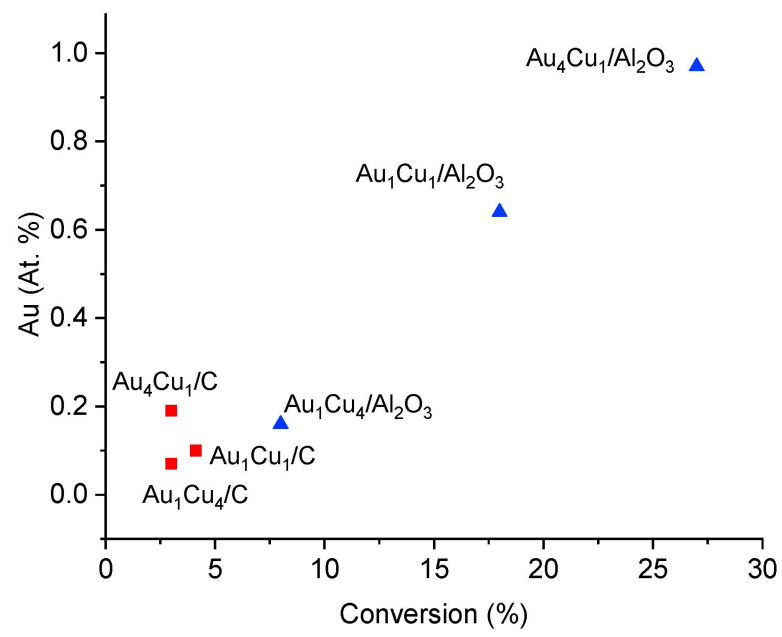

Figure 11. Influence of gold surface exposure on the conversion of VA after $1 \mathrm{~h}$. 
Table 3. Amount of exposed metal and gold exposure of $\mathrm{Al}_{2} \mathrm{O}_{3}$-supported catalysts.

\begin{tabular}{|c|c|c|c|c|c|}
\hline Catalysts & $\begin{array}{c}\text { Total Metal Amount } \\
\text { (\%At.) }\end{array}$ & $\begin{array}{c}\mathrm{Au} \\
(\% \mathrm{At} .)\end{array}$ & $\begin{array}{c}\mathrm{Au}^{0} \\
(\% \text { At. })\end{array}$ & $\begin{array}{l}A u^{0} \exp \\
(\% A t .)\end{array}$ & $\begin{array}{c}\text { Conversion_1h } \\
(\%)\end{array}$ \\
\hline $\mathrm{Au}_{4} \mathrm{Cu}_{1} / \mathrm{Al}_{2} \mathrm{O}_{3}$ & 1.50 & 97 & 78 & 76 & 25.6 \\
\hline $\mathrm{Au}_{1} \mathrm{Cu}_{1} / \mathrm{Al}_{2} \mathrm{O}_{3}$ & 1.48 & 64 & 83 & 53 & 12.4 \\
\hline $\mathrm{Au}_{1} \mathrm{Cu}_{4} / \mathrm{Al}_{2} \mathrm{O}_{3}$ & 1.52 & 16 & 100 & 16 & 7.27 \\
\hline
\end{tabular}

Due to the low conversion of C-supported catalyst, we decided to focus our attention on $\mathrm{Al}_{2} \mathrm{O}_{3}$-supported bimetallic samples and their properties. The total surface metal exposure of these samples is about 1.5 at. \% (Table 3, Column 2), but the conversion at $1 \mathrm{~h}$ of reaction is very different. These can be ascribed to the presence of different amount of $\mathrm{Au}$ and $\mathrm{Cu}$ on the catalyst surface. Therefore, the influence of the two metals on VA oxidation was studied (Figure S5). Plotting the Au and $\mathrm{Cu}$ surface exposure versus conversion at $1 \mathrm{~h}$ of reaction, a linear correlation was established. The higher the amount of exposed $\mathrm{Cu}$, the lower the conversion. Therefore, the Au sites are suggested to be the active sites of the examined reaction which can be modified electronically and also geometrically by interaction and dilution with $\mathrm{Cu} / \mathrm{Cu}$-oxide.

To see which is the active phase of the reaction $\mathrm{Au}^{0}$ amount was considered. Taking into consideration the at. $\%$ of $\mathrm{Au}^{0}$, it seems that the conversion at $1 \mathrm{~h}$ of reaction is higher when the amount of metal $\mathrm{Au}$ is low. However, through performing a normalization of the $\mathrm{Au}^{0}$ exposure $\left(\mathrm{Au}^{0}{ }_{\text {exp }}\right)$ by multiplying the $\mathrm{Au}^{0}$ at. \% (Table 3, column 4) for the Au exposure (Table 3, column 3), more indicative results were obtained (Figure S6). Increasing the amount of exposed $\mathrm{Au}^{0}{ }_{\text {exp }}$ the conversion rises linearly. Therefore, we can hypothesize that the active phase in VA oxidation reaction is $\mathrm{Au}^{0}$.

Moreover, catalytic results reveal that bimetallic catalysts lead to a higher conversion of VA than monometallic $\mathrm{Au}$ after $6 \mathrm{~h}$. In fact, the reaction profile of VA oxidation using $\mathrm{Au} / \mathrm{Al}_{2} \mathrm{O}_{3}$ is typical of deactivated catalyst. We can hypothesize that cations of copper maintain the gold in a zero oxidation state at the origin of the synergistic effect, as reported for glycerol oxidation reactions [33].

\subsubsection{Stability Tests}

$\mathrm{Au}_{4} \mathrm{Cu}_{1}$ and $\mathrm{Au}_{1} \mathrm{Cu}_{1}$ supported on alumina showed the highest catalytic activity. Considering the different reaction profiles, which show a higher trend to deactivate in the case of $\mathrm{Au}_{4} \mathrm{Cu}_{1}$ despite the highest initial activity, we investigated both their life-times by carrying out recycling tests. As reported in Figure 10, $\mathrm{Au}_{4} \mathrm{Cu}_{1}$ after three runs reduced its activity by about $80 \%$, whereas $\mathrm{Au}_{1} \mathrm{Cu}_{1}$ shows a pretty good stability (Figure 12).

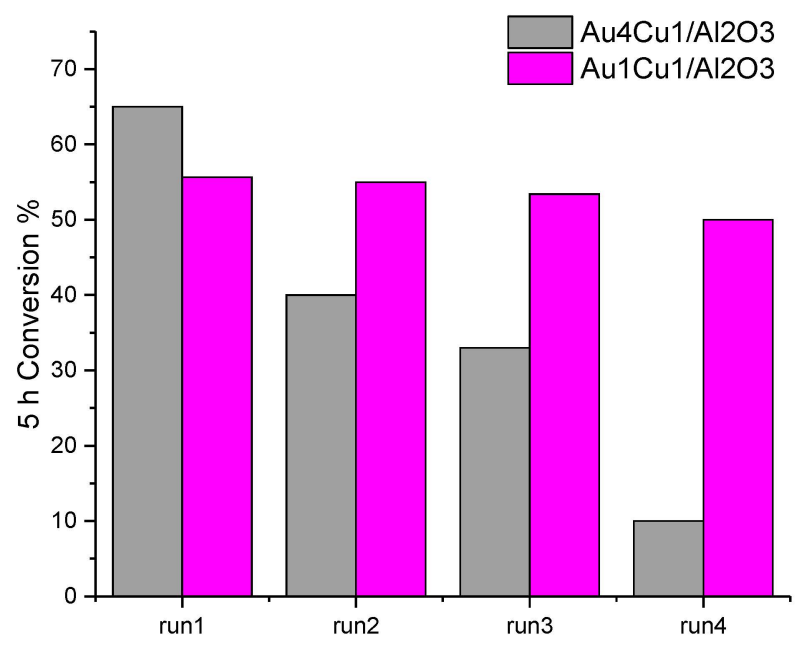

Figure 12. Recycle tests. VA oxidation in p-xylene $\left(0.15 \mathrm{~mol} \mathrm{~L}^{-1}\right)$, VA: metal molar ratio $1000: 1,80^{\circ} \mathrm{C}$ and 2 bar of $\mathrm{O}_{2}$. 
Thus, when copper is present in lower amounts than gold, the catalyst showed a high initial activity, but it tends to deactivate. On the other hand, when increasing the copper content, the stability of the catalytic material increases. ICP-OES measurements showed and confirmed that there is not leaching. Therefore, we ascribed the strong deactivation of $\mathrm{Au}_{4} \mathrm{Cu}_{1} / \mathrm{Al}_{2} \mathrm{O}_{3}$ to a competitive adsorption of (by)-products on the active site as reported in the literature [34]. By increasing the $\mathrm{Cu}$ content in the active phase, it was already observed [35] that there is an increase in stability of the catalytic performances.

\section{Materials and Methods}

Tetrachloroauric(III) acid trihydrate $\left(\mathrm{HAuCl}_{4} \cdot 3 \mathrm{H}_{2} \mathrm{O}, 99 \%\right.$ and copper(II) nitrate hydrate $\left(\mathrm{Cu}\left(\mathrm{NO}_{3}\right)_{2}\right.$ $\left.\cdot \mathrm{xH}_{2} \mathrm{O}, 99.999 \%\right)$ were used as precursors for the catalysts synthesis. Sodium borohydride $\left(\mathrm{NaBH}_{4}\right.$, powder, $\geq 98.0 \%$ ) was the reducing agent and polyvinyl alcohol (PVA, MW $=9000-10,000,80 \%$ hydrolysed) was used as the protecting agent. 3,4-dimetoxybenzyl alcohol (99\%), veratraldehyde (3,4-dimethoxybenzaldehyde, $\geq 98 \%$ ), p-xylene (anhydrous, $\geq 99 \%$ ) and undecane (reference standard for GC, Supelco,) were used without any further treatments. All the agents were purchased from Sigma Aldrich/Merck (Darmstadt, Germany).

Aqueous Au-Cu bimetallic and the corresponding monometallic sols of $\mathrm{Au} / \mathrm{Cu}=1 / 0,4 / 1,1 / 1,1 / 4$ and 0/1 molar ratio were fabricated by co-reduction of $\mathrm{HAuCl}_{4}$ and $\mathrm{Cu}\left(\mathrm{NO}_{3}\right)_{2}$ precursors with $\mathrm{NaBH}_{4}$ in the presence of polyvinyl alcohol (PVA) stabilizing agent. To a $685 \mathrm{ml}$ solution of metal precursors $(0.33 \mathrm{mM} \mathrm{Au}+\mathrm{Cu})$ and PVA $(0.013 \mathrm{wt} . \%) 75 \mathrm{ml}$ of $25.6 \mathrm{mM} \mathrm{NaBH}_{4}$ solution was added suddenly under vigorous stirring in an icy water bath and kept stirring for an hour. Three batches of a given sol were merged and its proper amounts were adsorbed on both alumina (Degussa Aluminium oxide C, $100 \mathrm{~m}^{2} / \mathrm{g}$,) and carbon (VULCAN ${ }^{\circledR}$ XC72R Carbon Black, Cabot, surface area of $218 \mathrm{~m}^{2} \mathrm{~g}^{-1}$, pore volume of $0.41 \mathrm{~mL} \mathrm{~g}^{-1}$, pore size $10.4 \mathrm{~nm}$, Boston, M.A., USA) [36] supports, providing $0.154 \mathrm{mmol} / \mathrm{gcat}$ metal $(\mathrm{Au}+\mathrm{Cu})$ loading. The suspension of the sols and supports were stirred overnight at room temperature, then filtered. After thorough washing with ultrapure water, the solids were dried overnight at $80^{\circ} \mathrm{C}$. C indicates the carbon black (Vulcan XC72R) support, while $\mathrm{Al}_{2} \mathrm{O}_{3}$ is used to name the alumina-supported catalysts. The complete samples list with details is reported in Table 4.

Table 4. Catalysts list, total metal loadings (wt. \%) and $\mathrm{Au} / \mathrm{Cu}$ theoretical molar ratio.

\begin{tabular}{cccc}
\hline Catalyst Label & $\mathbf{A u} / \mathbf{C u}$ Nominal Molar Ratio & ${\text { Metal Loading, wt. } \mathbf{o}^{\mathbf{a}}}$ & $\mathbf{A u C u}$ Particle Size, $\mathbf{n m}^{\mathbf{b}}$ \\
\hline $\mathrm{Au} / \mathrm{C}$ & - & 3 & $2.7 \pm 0.5$ \\
$\mathrm{Au}_{4} \mathrm{Cu}_{1} / \mathrm{C}$ & 4 & 2.6 & $2.0 \pm 0.6$ \\
$\mathrm{Au}_{1} \mathrm{Cu}_{1} / \mathrm{C}$ & 1 & 2 & $2.3 \pm 0.6$ \\
$\mathrm{Au}_{1} \mathrm{Cu}_{4} / \mathrm{C}$ & 0.25 & 1.4 & $1.9 \pm 0.6$ \\
$\mathrm{Cu} / \mathrm{C}$ & - & 1 & $2.9 \pm 0.5$ \\
$\mathrm{Au} / \mathrm{Al}_{2} \mathrm{O}_{3}$ & - & 3 & $2.0 \pm 0.5$ \\
$\mathrm{Au}_{4} \mathrm{Cu}_{1} / \mathrm{Al}_{2} \mathrm{O}_{3}$ & 4 & 2.6 & $1.8 \pm 0.5$ \\
$\mathrm{Au}_{1} \mathrm{Cu}_{1} / \mathrm{Al}_{2} \mathrm{O}_{3}$ & 1 & 2 & $1.9 \pm 0.4$ \\
$\mathrm{Au}_{1} \mathrm{Cu}_{4} / \mathrm{Al}_{2} \mathrm{O}_{3}$ & 0.25 & 1.4 & $1.7 \pm 0.4$ \\
$\mathrm{Cu} / \mathrm{Al}_{2} \mathrm{O}_{3}$ & - & 1 & $2.9 \pm 0.5$ \\
\hline \multicolumn{4}{r}{}
\end{tabular}

ICP-OES was performed using a ICP Perkin Elmer optical emission spectrometer Optima 8000 to check the real metal loading. Au-Cu-supported samples were dissolved using a CEM MARS One Microwave Digester For alumina-supported samples, digestion was performed using an acidic solution of $\mathrm{HCl}(37 \%)$ and $\mathrm{H}_{2} \mathrm{SO}_{4}(98 \%)$ in a 2:3 ratio at $180{ }^{\circ} \mathrm{C}(10 \mathrm{~min}$ temperature ramp-20 min maintenance-cooling down). For carbon-supported samples, the attack was performed with sulfonitric mixture $\left(\mathrm{HNO}_{3}: \mathrm{H}_{2} \mathrm{SO}_{4}\right.$ 1:3) first, then Au was dissolved by aqua regia $\left(\mathrm{HNO}_{3}: \mathrm{HCl} 1: 3\right)$.

STEM-EDS composition measurements and spectrum imaging of the parent sols and the alumina-supported $\mathrm{Au}_{1} \mathrm{Cu}_{1}$ catalyst drop-dried on molybdenum microgrids were performed. For this, a FEI Titan Themis $200 \mathrm{kV}$ Cs-corrected TEM transmission electron microscope (Eindoven, The Netherlands) 
with $0.09 \mathrm{~nm}$ HRTEM and $0.16 \mathrm{~nm}$ STEM resolution equipped with 4 Thermofischer EDS detectors was applied. Measured data were evaluated and elemental maps were created by using the Velox software.

EDX spectra () recorded in 80-500 scans of selected area were cumulated, depending on the stability of the particles during the measurements. For $\mathrm{Au}$ and $\mathrm{Cu}$ elemental maps, background corrected and fit $\mathrm{Au}-\mathrm{L}$ and $\mathrm{Cu}-\mathrm{K}$ intensities, respectively, were applied. $\mathrm{The} \mathrm{Au} / \mathrm{Cu}$ atomic ratio was calculated for various particles on area localized on HAADF image that was measured simultaneously with the STEM-EDS measurements.

UV-visible spectra of the parent sols and the alumina-supported samples were recorded by an Agilent Cary 60 spectrometer (Santa Clara, C.A., USA) in transmission and diffuse reflectance mode, respectively, to measure the localized surface plasmon resonance (LSPR) of the Au-and $\mathrm{Cu}$-containing nanoparticles.

X-ray photoelectron spectra (XPS) of the bimetallic samples were taken in an M-probe apparatus (Surface Science Instruments), for the determination of surface composition and oxidation state of the metals. The source was monochromatic $\mathrm{Al} \mathrm{K}$ radiation $(1486.6 \mathrm{eV})$. Data processing was performed by Esca Hawk software. The XPS lines of $\mathrm{C} 1 \mathrm{~s}, \mathrm{O} 1 \mathrm{~s}, \mathrm{Au} 4 \mathrm{f}$ and $\mathrm{Cu} 2 \mathrm{p}$ regions were recorded.

High angular annular dark field scanning transmission electron microscopy (HAADF-STEM) analysis was carried out using a ZEISS LIBRA200FE microscope equipped with a $200 \mathrm{kV}$ FEG source. Before the analysis, the samples were finely smashed in an agate mortar, suspended in isopropanol and sonicated, then each suspension was dropped onto a lacey carbon-coated copper grid (300 mesh) and the solvent was evaporated. Histograms of the particle size distribution were obtained by counting onto the micrographs at least 300 particles. The mean particle diameter $\left(\mathrm{d}_{\mathrm{m}}\right)$ was calculated by using the formula $\mathrm{d}_{\mathrm{m}}=\Sigma \mathrm{d}_{\mathrm{i}} \mathrm{n}_{\mathrm{i}} / \Sigma \mathrm{n}_{\mathrm{i}}$ where $\mathrm{n}_{\mathrm{i}}$ was the number of particles of diameter $\mathrm{d}_{\mathrm{i}}$. The standard deviation was calculated by using the formula $\mathrm{SD}=\left[\Sigma \mathrm{n}_{\mathrm{i}}\left(\mathrm{d}_{\mathrm{i}}-\mathrm{d}_{\mathrm{m}}\right)^{2} / \mathrm{n}_{\mathrm{i}}\right]^{0.5}$.

The mono- and bimetallic Au-Cu catalysts were tested for the oxidation of 3,4-dimetoxybenzyl alcohol (veratryl alcohol, VA). Oxidation reactions were carried out in $100 \mathrm{~mL}$ stainless steel autoclave equipped with a glass inlet. In a typical experiment, $10 \mathrm{ml}$ of a solution of veratryl alcohol in p-xylene $\left(0.15 \mathrm{~mol} \mathrm{~L}^{-1}\right)$ and an appropriate amount of catalyst (VA:metal molar ratio 1000:1) were placed into the autoclave along with a magnetic stirrer. The system was flushed three times with $\mathrm{O}_{2}$ first in order to remove any residual air in the atmosphere and then pressurized with 2 bar of $\mathrm{O}_{2}$. The reaction was then heated at $80^{\circ} \mathrm{C}$ and the solution stirred at a constant stirring rate of $1250 \mathrm{rpm}$. Samplings were carried out by stopping the stirring and quenching the reaction in an ice bath. A sample of solution was withdrawn and centrifuged in order to separate the catalyst. The products of reaction were identified by GC-MS (Thermo Scientific TRACE 1300 equipped with an Agilent HP-5 column, using undecane as external standard.

Recycling tests were carried out by recovering the catalyst after the reaction and re-using it without any further treatment with a fresh solution of VA.

\section{Conclusions}

Veratryl alcohol (VA) has been used as model for a lignin degradation product but also represents an important starting material for fragrances and additives, i.e., veratryl aldehyde. We report the study of AuCu bimetallic catalysts in the oxidation of VA using the sol immobilization technique. This latter technique was used for limiting differences in particle size by varying the $\mathrm{Au} / \mathrm{Cu}$ ratio and the support. Indeed, we limited any difference in particle size within the series of catalysts prepared. We investigated $\mathrm{Au} / \mathrm{Cu}$ molar ratios of 4, 1 and 0.25 using alumina and activated carbon as the support.

In the catalytic performance, we observed a strong dependence on the type of support used, being catalysts on $\mathrm{Al}_{2} \mathrm{O}_{3}$ definitely more active than the ones on carbon. UV-Vis and EDX analysis confirmed the bimetallic nature of the particles. In particular, $\mathrm{Au}_{4} \mathrm{Cu}_{1}$ and $\mathrm{Au}_{1} \mathrm{Cu}_{4}$ are, respectively, more rich in $\mathrm{Au}$ and $\mathrm{Cu}$. XPS showed surface enrichment (even in different extents) of the major component and a higher metal exposure for $\mathrm{Al}_{2} \mathrm{O}_{3}$-supported catalysts. Moreover, the support effect was verified by comparing activities of catalysts with the same metal exposure. We also found that a linear correlation 
can be established between conversion and gold surface exposure defining Au as the active phase. In particular, it was disclosed that $\mathrm{Au}^{0}$ species is the active metal center of VA oxidation reaction. We concluded that the most active catalyst in VA oxidation was $\mathrm{Au}_{4} \mathrm{Cu}_{1}$ supported on $\mathrm{Al}_{2} \mathrm{O}_{3}$, even though the most stable appeared to be the $\mathrm{Au}_{1} \mathrm{Cu}_{1}$ one.

Supplementary Materials: The following are available online at http://www.mdpi.com/2073-4344/10/3/332/s1, Figure S1: $\mathrm{Cu} 2 \mathrm{p}$ deconvolution for $(\mathrm{A}) \mathrm{Au}_{4} \mathrm{Cu}_{1}$ (B) $\mathrm{Au}_{1} \mathrm{Cu}_{1}$ and (C) $\mathrm{Au}_{1} \mathrm{Cu}_{4}$ C-supported catalysts, Figure S2: $\mathrm{Cu} 2 \mathrm{p}$ deconvolution for (A) $\mathrm{Au}_{4} \mathrm{Cu}_{1}$ (B) $\mathrm{Au}_{1} \mathrm{Cu}_{1}$ and (C) $\mathrm{Au}_{1} \mathrm{Cu}_{4} \mathrm{Al}_{2} \mathrm{O}_{3}$-supported catalysts, Figure $\mathrm{S} 3$ : $\mathrm{Au} 4 \mathrm{f}$ deconvolution for $(\mathbf{A}) \mathrm{Au}_{1} \mathrm{Cu}_{1}$ (B) $\mathrm{Au}_{4} \mathrm{Cu}_{1}$ C-supported catalysts, Figure S4: $\mathrm{Au} 4 \mathrm{f}$ deconvolution for $(\mathbf{A}) \mathrm{Au}_{1} \mathrm{Cu}_{1}$ (B) $\mathrm{Au}_{4} \mathrm{Cu}_{1} \mathrm{Al}_{2} \mathrm{O}_{3}$-supported catalysts, Figure S5: Influence of (A) gold and (B) copper surface exposure on the conversion of VA after $1 \mathrm{~h}$ for $\mathrm{Al}_{2} \mathrm{O}_{3}$ supported catalysts, Figure S6: Influence of $\mathrm{Au}^{0}$ exp exposure on the conversion at $1 \mathrm{~h}$ of reaction.

Author Contributions: Conceptualization, M.S. and A.V.; methodology, A.J.; validation, S.C. (Sofia Capelli), S.C. (Simone Cardaci); formal analysis, A.B. and G.S.; investigation, A.B. and M.S.; data curation, M.S. and S.C. (Simone Cardaci); writing-original draft preparation, M.S.; writing-review and editing, M.S., S.C. (Stefano Cattaneo) and L.P.; supervision, L.P.; project administration, L.P.; funding acquisition, L.P. and C.E. All authors have read and agreed to the published version of the manuscript.

Funding: This research received no external funding.

Acknowledgments: Authors gratefully acknowledge Gergely NAGY (Centre for Energy Research, Surface Chemistry and Catalysis Department, P.O. Box 49, Budapest H-1525, Hungary) for the preparation of the catalysts and for the UV-vis measurements. We also acknowledge the support of Hungarian national project VEKOP-2.3.3-15-2016-00002 (In the frame of this was purchased the Themis microscope).

Conflicts of Interest: The authors declare no conflict of interest.

\section{References}

1. Bruijnincx, P.C.A.; Weckhuysen, B.M. Lignin up for break-down. Nat. Chem. 2014, 6, 1035-1036. [CrossRef]

2. Heitner, C.; Schmidt, J.A.; Group, F. Lignin and Lignans; CRC Press: Boca Raton, FL, USA, 2016.

3. Zakzeski, J.; Bruijnincx, P.C.A.; Jongerius, A.L.; Weckhuysen, B.M. The catalytic valorization of lignin for the production of renewable chemicals. Chem. Rev. 2010, 110, 3552-3599. [CrossRef]

4. Wang, Z. Green Chemistry: Recent Advances in Developing Catalytic Processes in Environmentally-Benign Solvent Systems. Available online: http://ccc.chem.pitt.edu/wipf/frontiers/zhiyong.pdf (accessed on 1 February 2020).

5. Zakzeski, J.; Jongerius, A.L.; Weckhuysen, B.M. Transition metal catalyzed oxidation of Alcell lignin, soda lignin, and lignin model compounds in ionic liquids. Green Chem. 2010, 12, 1225-1236. [CrossRef]

6. Wu, X.; Guo, S.; Zhang, J. Selective oxidation of veratryl alcohol with composites of Au nanoparticles and graphene quantum dots as catalysts. Chem. Commun. 2015, 51, 6318-6321. [CrossRef]

7. Díaz-González, M.; Vidal, T.; Tzanov, T. Phenolic compounds as enhancers in enzymatic and electrochemical oxidation of veratryl alcohol and lignins. Appl. Microbiol. Biotechnol. 2011, 89, 1693-1700. [CrossRef] [PubMed]

8. Gutman, A.L.; Shkolnik, E.; Tishin, B.; Nisnevich, G. Process and Intermediates for Production of Donepezil and Related Compounds. U.S. Patent 6492522B1, 10 December 2002.

9. Lahtinen, P.; Korpi, H.; Haavisto, E.; Leskelä, M.; Repo, T. Parallel screening of homogeneous copper catalysts for the oxidation of benzylic alcohols with molecular oxygen in aqueous solutions. J. Comb. Chem. 2004, 6, 967-973. [CrossRef] [PubMed]

10. Mate, V.R.; Shirai, M.; Rode, C.V. Heterogeneous $\mathrm{Co} 3 \mathrm{O} 4$ catalyst for selective oxidation of aqueous veratryl alcohol using molecular oxygen. Catal. Commun. 2013, 33, 66-69. [CrossRef]

11. Melián-Rodríguez, M.; Saravanamurugan, S.; Kegnæs, S.; Riisager, A. Aerobic Oxidation of Veratryl Alcohol to Veratraldehyde with Heterogeneous Ruthenium Catalysts. Top. Catal. 2015, 58, 1036-1042. [CrossRef]

12. Stucchi, M.; Cattaneo, S.; Cappella, A.; Wang, W.; Wang, D.; Villa, A.; Prati, L. Catalytic Oxidation of Methoxy Substituted Benzyl Alcohols as Model for Lignin Valorisation. Catal. Today 2019. [CrossRef]

13. Olmos, C.M.; Chinchilla, L.E.; Cappella, A.M.; Villa, A.; Delgado, J.J.; Hungría, A.B.; Blanco, G.; Calvino, J.J.; Prati, L.; Chen, X. Selective oxidation of veratryl alcohol over Au-Pd/Ce0.62Zr0.38O2 catalysts synthesized by sol-immobilization: Effect of Au:Pd molar ratio. Nanomaterials 2018, 8, 669. [CrossRef]

14. Haruta, M.; Kobayashi, T.; Sano, H.; Yamada, N. Novel Gold Catalysts for the Oxidation of Carbon Monoxide at a Temperature far Below $0{ }^{\circ} \mathrm{C}$. Chem. Lett. 1987, 16, 405-408. [CrossRef] 
15. Hutchings, G.J. Vapor phase hydrochlorination of acetylene: Correlation of catalytic activity of supported metal chloride catalysts. J. Catal. 1985, 96, 292-295. [CrossRef]

16. Silva, T.A.G.; Teixeira-Neto, E.; López, N.; Rossi, L.M. Volcano-like behavior of Au-Pd core-shell nanoparticles in the selective oxidation of alcohols. Sci. Rep. 2014, 4, 5766. [CrossRef] [PubMed]

17. Cattaneo, S.; Stucchi, M.; Villa, A.; Prati, L. Gold Catalysts for the Selective Oxidation of Biomass-Derived Products. Chem CatChem 2019, 11, 309-323. [CrossRef]

18. Schwank, J. Gold in bimetallic catalysts. Gold Bull. 1985, 18, 2-10. [CrossRef]

19. Markó, I.E.; Giles, P.R.; Tsukazaki, M.; Brown, S.M.; Urch, C.J. Copper-catalyzed oxidation of alcohols to aldehydes and ketones: An efficient, aerobic alternative. Science 1996, 274, 2044-2046. [CrossRef]

20. Albadi, J.; Alihoseinzadeh, A.; Razeghi, A. Novel metal oxide nanocomposite of $\mathrm{Au} / \mathrm{CuO}-\mathrm{ZnO}$ for recyclable catalytic aerobic oxidation of alcohols in water. Catal. Commun. 2014, 49, 1-5. [CrossRef]

21. Zhan, W.; Wang, J.; Wang, H.; Zhang, J.; Liu, X.; Zhang, P.; Chi, M.; Guo, Y.; Guo, Y.; Lu, G.; et al. Crystal Structural Effect of AuCu Alloy Nanoparticles on Catalytic CO Oxidation. J. Am. Chem. Soc. 2017, 139, 8846-8854. [CrossRef]

22. Destro, P.; Marras, S.; Manna, L.; Colombo, M.; Zanchet, D. AuCu alloy nanoparticles supported on SiO2: Impact of redox pretreatments in the catalyst performance in CO oxidation. Catal. Today 2017, 282, 105-110. [CrossRef]

23. Della Pina, C.; Falletta, E.; Rossi, M. Highly selective oxidation of benzyl alcohol to benzaldehyde catalyzed by bimetallic gold-copper catalyst. J. Catal. 2008, 260, 384-386. [CrossRef]

24. Marelli, M.; Jouve, A.; Villa, A.; Psaro, R.; Balerna, A.; Prati, L.; Evangelisti, C. Hybrid Au/CuO Nanoparticles: Effect of Structural Features for Selective Benzyl Alcohol Oxidation. J. Phys. Chem. C 2019, 123, 2864-2871. [CrossRef]

25. Liu, X.; Wang, A.; Li, L.; Zhang, T.; Mou, C.-Y.; Lee, J.-F. Structural changes of Au-Cu bimetallic catalysts in CO oxidation: In situ XRD, EPR, XANES, and FT-IR characterizations. J. Catal. 2011, 278, 288-296. [CrossRef]

26. Amendola, V.; Pilot, R.; Frasconi, M.; Maragò, O.M.; Iatì, M.A. Surface plasmon resonance in gold nanoparticles: A review. J. Phys. Condens. Matter 2017, 29, 203002. [CrossRef] [PubMed]

27. Daniel, M.C.; Astruc, D. Gold Nanoparticles: Assembly, Supramolecular Chemistry, Quantum-Size-Related Properties, and Applications Toward Biology, Catalysis, and Nanotechnology. Chem. Rev. 2004, 104, 293-346. [CrossRef] [PubMed]

28. Creighton, J.A.; Eadon, D.G. Ultraviolet-visible absorption spectra of the colloidal metallic elements. J. Chem. Soc. Faraday Trans. 1991, 87, 3881-3891. [CrossRef]

29. Lisiecki, I.; Pileni, M.P. Copper metallic particles synthesized "in situ" in reverse micelles: Influence of various parameters on the size of the particles. J. Phys. Chem. 1995, 99, 5077-5082. [CrossRef]

30. Luo, Y.; Tu, Y.; Ren, Q.; Dai, X.; Xing, L.; Li, J. Surfactant-free fabrication of $\mathrm{Cu}_{2} \mathrm{O}$ nanosheets from Cu colloids and their tunable optical properties. J. Solid State Chem. 2009, 182, 182-186. [CrossRef]

31. Xu, Z.; Lai, E.; Yang, S.H.; Hamad-Schifferli, K. Compositional dependence of the stability of AuCu alloy nanoparticles. Chem. Commun. 2012, 48, 5626-5628. [CrossRef]

32. Wang, H.; Liu, D.; Xu, C. Directed synthesis of well dispersed and highly active AuCu and AuNi nanoparticle catalysts. Catal. Sci. Technol. 2016, 6, 7137-7150. [CrossRef]

33. Schünemann, S.; Dodekatos, G.; Tüysüz, H. Mesoporous Silica Supported Au and AuCu Nanoparticles for Surface Plasmon Driven Glycerol Oxidation. Chem. Mater. 2015, 27, 7743-7750. [CrossRef]

34. Casanova, O.; Iborra, S.; Corma, A. Biomass into chemicals: Aerobic oxidation of 5-hydroxymethyl-2-furfural into 2,5-furandicarboxylic acid with gold nanoparticle catalysts. ChemSusChem. 2009, 2, 1138-1144. [CrossRef] [PubMed]

35. Albonetti, S.; Pasini, T.; Lolli, A.; Blosi, M.; Piccinini, M.; Dimitratos, N.; Lopez-Sanchez, J.A.; Morgan, D.J.; Carley, A.F.; Hutchings, G.J.; et al. Selective oxidation of 5-hydroxymethyl-2-furfural over TiO 2-supported gold-copper catalysts prepared from preformed nanoparticles: Effect of Au/Cu ratio. Catal. Today 2012, 195, 120-126. [CrossRef]

36. Moore, A.D.; Holmes, S.M.; Roberts, E.P.L. Evaluation of porous carbon substrates as catalyst supports for the cathode of direct methanol fuel cells. RSC Adv. 2012, 2, 1669-1674. [CrossRef] 